\title{
RESEARCH ARTICLE \\ MODELING FLOOD HAZARD USING SWAT AND 3D ANALYSIS IN TERENGGANU WATERSHED
}

\author{
Ibrahim Sufiyan ${ }^{1 *}$, J.I Magaji ${ }^{2}$ \\ Department of Geography, Nasarawa State University Keffi, Nigeria \\ *Corresponding Author Email: ibrahimsufiyan0@gmail.com
}

This is an open access article distributed under the Creative Commons Attribution License, which permits unrestricted use, distribution, and reproduction in any medium, provided the original work is properly cited

\section{ARTICLE DETAILS}

\section{Article History:}

Received 1 January 2019

Accepted 7 February 2019

Available online 13 February 2019

\section{ABSTRACT}

One of the anthropogenic interference is the modification of natural habitat into the man-made environment, such as agriculture, urbanization mining, lumbering as well as industrialization. The kenyir lake as an artificial lake, attract tourist from all over the world because of its natural beauty sustainable development an eco-tourism attraction. This study will focus on how the natural landscape will be conserved and what is the composition of the land cover surrounding the Lake kenyir. The current issues that course for concern are the changes observed and detected from the land use, land cover (LULC) through the use of soil water assessment tool (SWAT) ArcSWAT 2012. The study area was finally characterized by a delineated watershed, sub-basin parameters for calculation of hydrologic response units (HRUs). this includes the nature and orientation of the slope; digital elevation model (DEM), local soil classification and the land cover found around the environment. The 3D simulation was applied to predict the flow of water from the subbasins and from the lake that drained into a larger body of water toward the river mouth of Kuala Terengganu to empty into the South China Sea.

\section{KEYWORDS}

SWAT, 3D Simulation, Flood Risk, Modeling

\section{INTRODUCTION}

The ability to solve the environmental problem is paramount particularly with the application of appropriate technology of geographic information system (GIS). This study focuses on the mitigation of flood hazard event in River Terengganu. The idea is to develop a model reflecting on the existing data available. The GIS extension of ArcSWAT will be used to analyze the data. There are many issues concerning the flood mitigation hazard; this includes an impact assessment of land cover and land uses, the river flows and the sediment yield at the river Terengganu. The method adopted was the simulation of the model in ArcSWAT, calibration and validation are possible. The output or result can be in the form of charts, graphs, models, tables, and maps. The display will determine the predicted outcomes. The surrounding areas liable to flooding will be identified by digital elevation model (DEM). The DEM can show the relationship between the catchment area and the flood-prone areas within the scope of this study.

Currently, flood events are a part of nature. They have existed and will continue to live. The flood hazard affects human beings as well as natural habitats such as our environment and components. According to a researcher, the annually flooding causes more damages to properties in the United States more than many countries [1]. Considering the evolution and trends, the approach to physical hazards requires quick attention. The idea is to access the ways of reducing the flood risk and hazard event in most of the places where flood occurs.

According to a scholar, flood can be defined as a high water flow naturally or artificially from the river bank that dominates the surrounding area to cause overflow [2]. The high flow of the water may extend over the floodplain and it becomes a hazard to the society. Climate change becomes the dominant factor in a situation like a flood event. When the flood occurred, it might result in a high risk of life, properties as well as the environment. Therefore, flood hazard can be viewed as a natural event that can disrupt day to day activities and hindered economic growth, create environmental pollution and outbreak of diseases. The application of geographic information system (GIS) will help in monitoring and evaluation, assessing and modeling, mapping hazard and mitigation, help in visualization and management.

The river flow direction indicates the water flow toward the lower slope or elevation zones where the primary Terengganu River catchment has an outlet into the South China Sea. The rivers that formed sub-basins from the artificial Kenyir Lake are all drained into the other adjacent outlets. The flow was affected by the presence of reservoirs which are used for other human benefits, such as Hydro-Electric Power (HEP) generation, Dam construction, Irrigational purposes, and for recreation and tourism. Therefore, it is therefore paramount to develop the lake and Dam to harness the economy base on the river flow direction and the water supply from the watershed. According to these results, flow accumulation and directions in the catchment area of Terengganu River catchment will be a focus on capital development for anthropogenic uses. There are two categories of floods in Malaysia which have been classified by Malaysian Drainage and Irrigation Department; these are a flash flood and monsoon floods and the areas around the coast are being flooding [3]. According to the two different perspectives of floods, the hydrologic point of view, the flash flood is not intense for it only takes some few hours to return to average level, while the monsoonal flood may last for a month or more [4]. Flood is one of the naturally occurring phenomena that affect Malaysia. The hazard and the risk go beyond a reasonable doubt. The Malaysian government sent large sum to control and manage flood disaster from 1926 to 2001 around RM 915 million was estimated to be spent [5]. 
The types of sediment transport and the frequency of the flood occurrence [6]. The SWAT or Soil Water Assessment Tools is a physically based, continuous time calculation of hydrologic model [7]. It was designed to predict daily streamflow activities, nutrient losses, soil analysis and sediment yield in a watershed. Several studies previously showed and indicated promising results using SWAT as a hydrologic model. These includes; the work of prevoius researchers respectively [8-14].

\section{METHODOLOGY}

This study was base on the modeling and simulation in other to predict and detect possible hazard of flood and the influence of land use and land cover on the artificially developed lake (Kenyir Lake) in Terengganu river catchment. According to several researchers, SWAT is increasingly being used in the watershed hydrological processes widely accepted and understood for evaluation of modeling application $[15,16]$. According toa scholar, SWAT explored the degree of complexity on spatial variables in the watershed for examination of parameters [17]. The input data are not only affected by parameters but also modifies the inbuilt model structure.

\subsection{Study Area}

Terengganu River catchment is located at upper left corner $50^{\circ} 30^{1} .40^{11} \mathrm{~N}$, $102^{\circ} 23^{\mathrm{I}} 15^{\mathrm{II}} \mathrm{E}$ and the lower right corner is $40^{\circ} 39^{\mathrm{I}} 25^{\mathrm{II}} \mathrm{N}, 103^{\circ} 11^{\mathrm{I}} 62^{\mathrm{II}} \mathrm{E}$. The figure 1 below shows the Lake Kenyir and the influence of land use/land cover within the catchment area. Terengganu is located on the east coast of Peninsula Malaysia which is experiencing heavy rainfall during the Northeast monsoon occurs between October and March that has resulted in a flood in most of Malaysia. But most of the coastal areas along the Eastern location including Terengganu were affected by coastal flooding [18]. Another flood event that concurrently happened in Malaysia, were in Johor, Pahang, Melaka and Negara Sembilan. It is essential to identify land cover changes and their classification over time for easy comparison [19]. For instance, the forest land cover changes in Peninsula Malaysia.

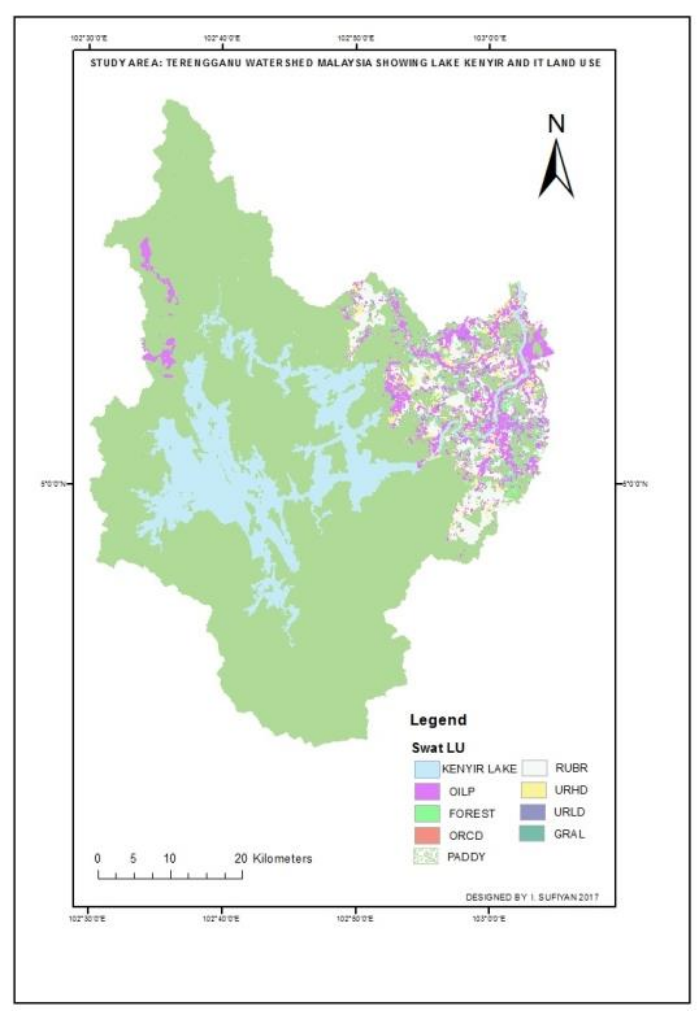

Figure 1: Position of Kenyir Lake within the Terengganu Watershed The watershed of Terengganu is surrounded by a network of the stream as in figure 2, and the SWAT categorized them into sub-basins for easier identification. Each of this sub-basins parameter was defined by hydrologic response unit. The figure 9 below illustrates them according to the number of functions each of the sub-basin performed.

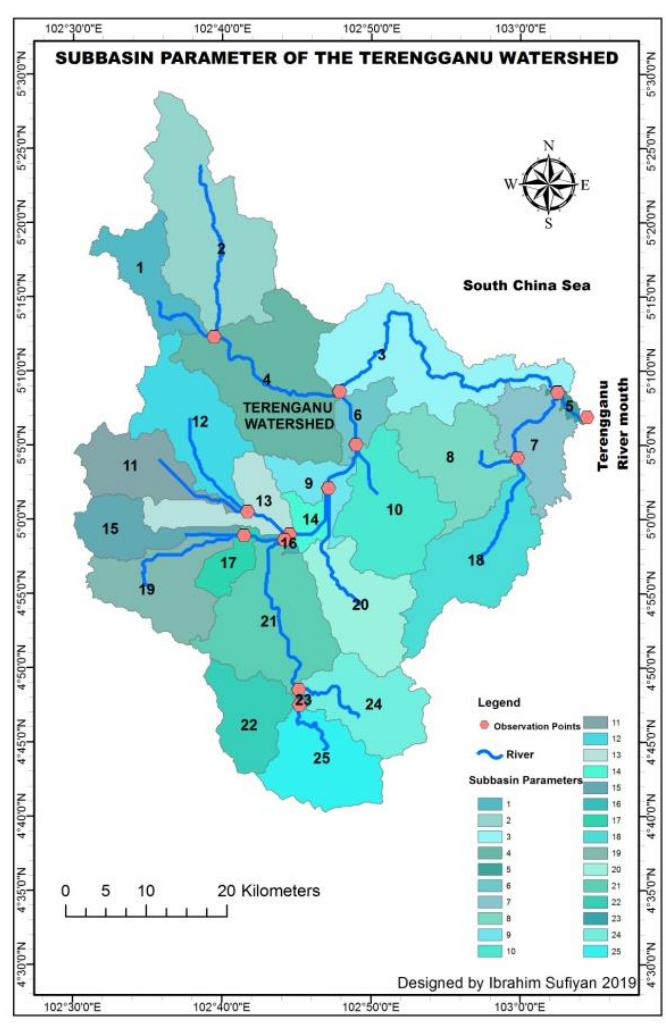

Figure 2: Sub-basins and Stream network in Terengganu catchment The study flow is used for demonstration of a summary of work from the data acquisition up to the result obtained. The SWAT and the 3D modeling were both performed in ArcGIS 10.3 as shown in figure 3.

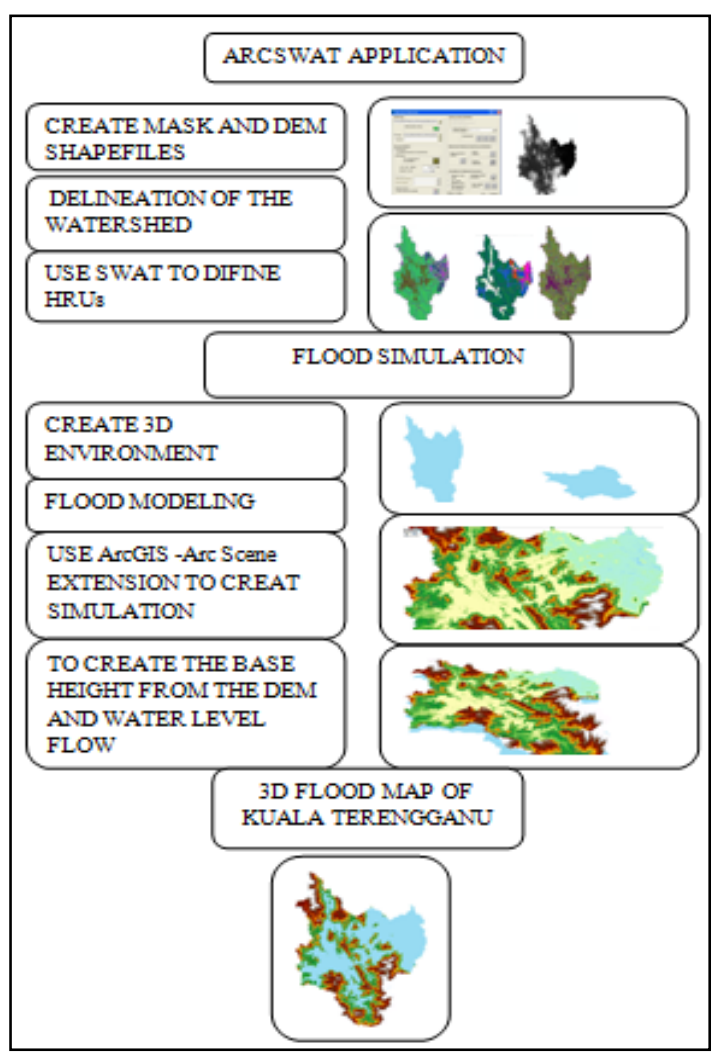

Figure 3: flow chart of the study

\subsection{SWAT Data Sources}

1. Department of Irrigation and Drainage (DID)

a. Data for a flood event in the study area (previously)

b. Stream flows data These are obtainable base on a different location of the stations 
2. Climate data from the Malaysian Meteorological Department (MET Malaysia) from 2000-2015

3. Land cover images from Malaysian Remote Sensing Agency (MRSA)

4. Malaysian soil map was obtainable from online source European Digital Archives of soil maps (EuDASM) named Reconnaissance soil map Peninsular Malaysia 1968.

\subsection{Digital Elevation Model (DEM)}

The digital elevation model was obtained from the Landsat satellite data and converted it to (.tiff) image and transformed or projected into Kertua RSO Malaya Meters. The 30-meter resolution DEM was clipped to Terengganu River catchment

The river network was burn-in together with the DEM (.tiff) file forming the watershed as shown in figure 4 below.

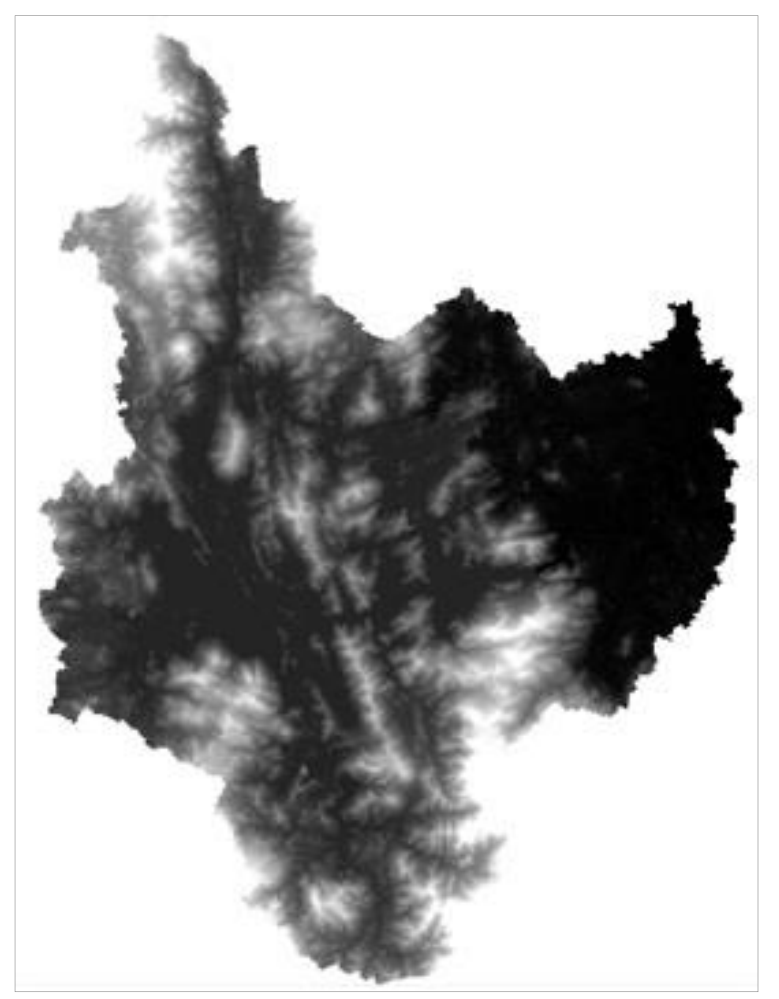

Figure 4: Digital Elevation Model (DEM) 30M Resolutions of Terengganu River catchment

\section{RESULT AND DISCUSSION}

The study focuses on the flood mitigation in one of the flood-prone regions in the Eastern part of Peninsula Malaysia called Kuala Terengganu River Catchment. The Terengganu catchment has a total area of stream definition of $5,730.1452$ [Ha] about $14,159.497$ acres or $57.401 \mathrm{~km}^{2}$ with cells value of 63,668 .

\subsection{Hydrologic Response Units (HRUs)}

The hydrologic response units (HRUs) results in consist of the land use, soil types, and the catchment slope. They are characterized by unique performance and distributions of the individual report within the catchment area. In this study, we are able to find out the following results as shown in table 1,2 and 3 respectively.

\subsection{Land Use/Cover Results}

Table 1 below presents the SWAT output from one of the HRU result. The land cover plays a vital role in controlling the climate as well as the water flow that causes a flood. The forest land cover for instance in the study area is the major predominant land cover. If some portion of the forest is removed, the flood will inundate other regions occupying the lower elevations.
Table 1: Land Use Results

\begin{tabular}{|l|l|l|l|l|}
\hline Land use & Abbreviation & Area [ha] & Area[acres] & $\begin{array}{l}\text { \%wat. } \\
\text { Area }\end{array}$ \\
\hline Water Body & WATR & $42,684.6541$ & $105,475.9145$ & 14.90 \\
\hline $\begin{array}{l}\text { Residential-High } \\
\text { Density }\end{array}$ & URHD & $3,346.7332$ & $8,269.9450$ & 1.17 \\
\hline Orchard & ORCD & 46.8465 & 115.7601 & 0.02 \\
\hline Rubber Trees & RUBR & $11,981.4471$ & $29,606.7548$ & 4.18 \\
\hline $\begin{array}{l}\text { Residential-Low } \\
\text { Density }\end{array}$ & URLD & 167.2060 & 413.1745 & 0.06 \\
\hline Oil Palm & OILP & $13,251.0778$ & $32,744.0757$ & 4.63 \\
\hline Paddy & PADD & $3,209.3467$ & $7,930.4563$ & 1.12 \\
\hline Grassland & GRSS & 10.9008 & 26.9365 & 0.00 \\
\hline Forest-Evergreen & FRSE & $211,809.1378$ & $523,390.9698$ & 73.93 \\
\hline
\end{tabular}

Figure 5 depicts the land cover map of the Kuala Terengganu catchment The legend below explains the different pattern of the land cover which includes forest, water, urban land use, rubber, paddy, orchard, oil palm and grassland. The Terengganu catchment was entirely occupied by forest evergreen where most of the forest products are found. The map in figure 5 has represented the forest evergreen as the predominant land cover in the whole of the study area.

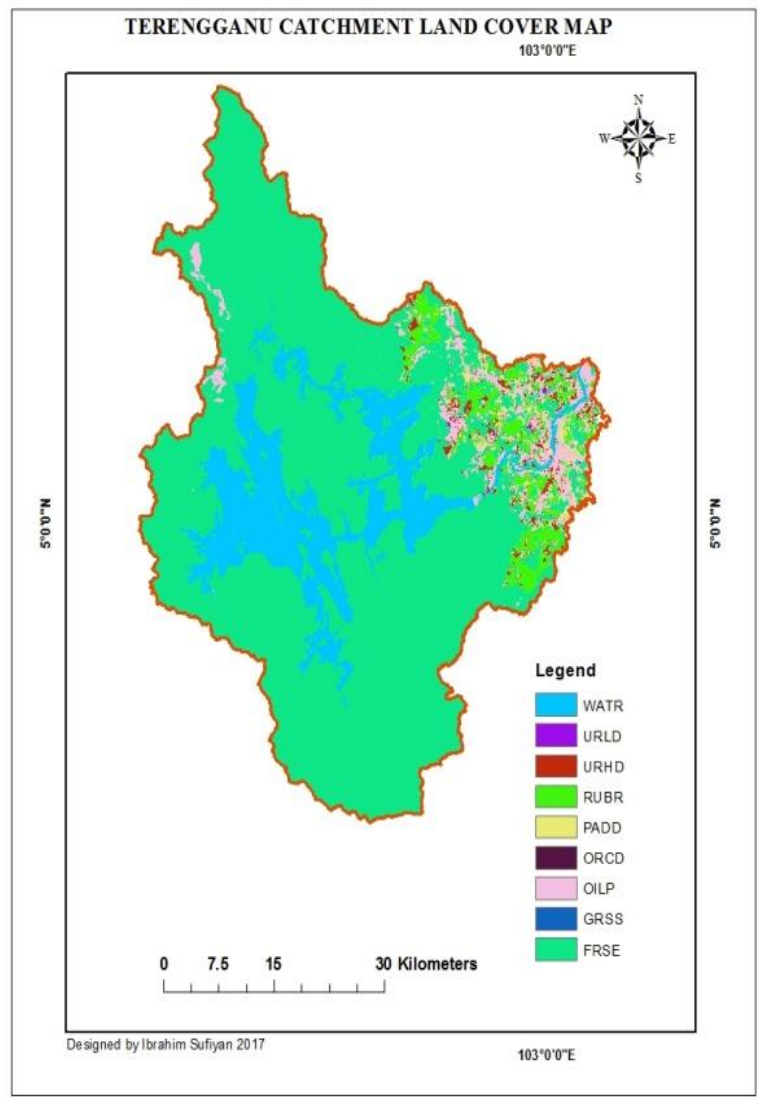

Figure 5: Land Use classification of Terengganu River catchment

\subsection{Soil Types Classification Results}

The soils classification was base on the USGS with default SWAT and has the ability to update the local soil database. The local soils in the study area are edited base on the SWAT update from the existing soils of the world. Table 2 shows the result of the soil classification with total regions of hectares, acres as well as the overall percent obtained during the analysis. 
Table 2: Soil types result

\begin{tabular}{|l|l|l|l|}
\hline Soils & Area [ha] & Area[acres] & $\begin{array}{l}\text { \% wat. } \\
\text { Area }\end{array}$ \\
\hline Kuala Brang & $35,604.8842$ & $87,981.4491$ & 12.43 \\
\hline Marang & $26,762.6042$ & $66,131.7330$ & 9.34 \\
\hline Peat & $47,32.3090$ & $11,693.7721$ & 1.65 \\
\hline Rudua & $1,357.6481$ & $3,354.8163$ & 0.47 \\
\hline Steepland & $200,117.6886$ & $494,500.8145$ & 69.85 \\
\hline Telemong & $10,250.0178$ & $25,328.3066$ & 3.58 \\
\hline Tok Yong & $7,682.1981$ & $18,983.0956$ & 2.68 \\
\hline
\end{tabular}

Figure 6 presents the digitized soil map of the Kuala Terengganu catchment. The Soils has the ability to absorb moisture and get cooler and hotter quickly. Depending on the temperature, the water retention capacity varies from wet equatorial climate to monsoon as well as arid and semi-arid environment. The predominant local soil in the Terengganu River catchment is steep and with the highest elevation; most of these areas around the steel and are flood risk-free zones.

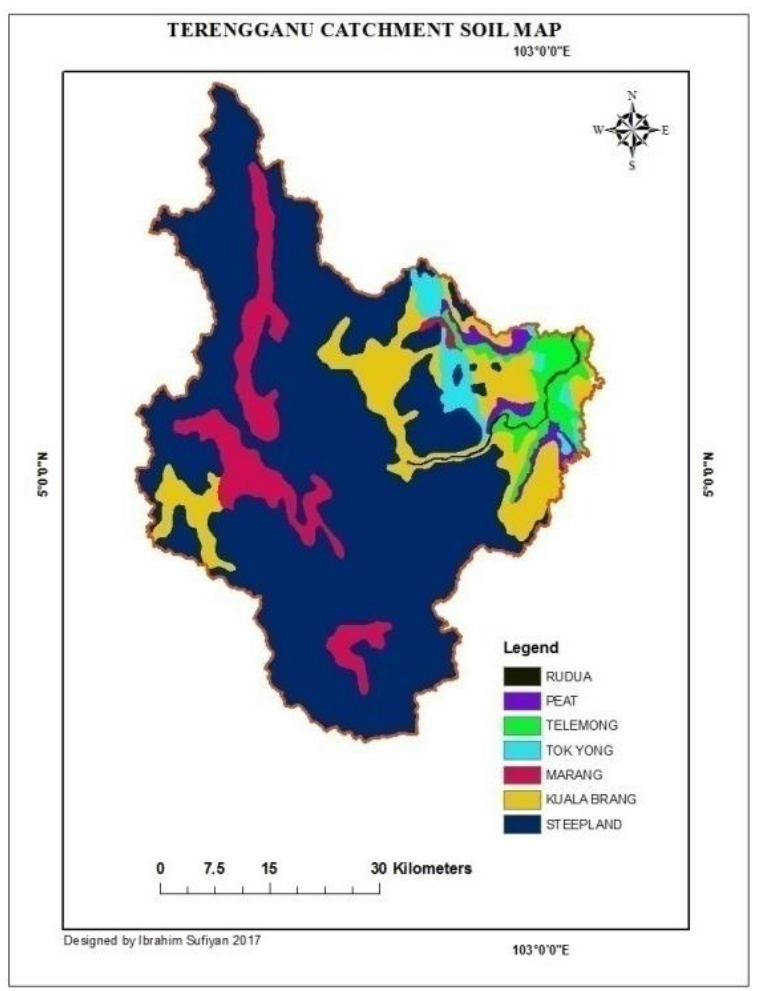

Figure 6: Soil map of Kuala Terengganu Catchment Area.

\subsection{Slope Analysis}

The slope data derived from the SWAT database was an inbuilt developed from the chosen threshold of 10/10/10 percent from the HRU. Table 3 shows the result of total area from each category of slope in hectares and acres while taking cognizance of slope percent from 0-10 up to 40 meters above.

From the table 3 below, we can also conclude that areas occupied by the steepland land cover having the highest elevation and most significant percentage of $66,130.4348$ hectares about $23.08 \%$. This justifies the result obtained from the soil classification model in figure 7 with steep land representing the most significant space in the Terengganu River catchment.

Table 3: Slope Results

\begin{tabular}{|l|l|l|l|}
\hline Slope & Area [ha] & Area[acres] & \%wat. Area \\
\hline $0-10$ & $62,167.7600$ & $153,619.6434$ & 21.70 \\
\hline $10-20$ & $59,973.9917$ & $148,198.7322$ & 20.93 \\
\hline $20-30$ & $543,92.6797$ & $134,407.0312$ & 18.98 \\
\hline $30-40$ & $43,842.4838$ & $108,336.9695$ & 15.30 \\
\hline $40-9999$ & $66,130.4348$ & $163,411.6109$ & 23.08 \\
\hline
\end{tabular}

The figure 7 below presents the elevation or slope map of the Kuala Terengganu catchment. The dark grey color depicts the lowest elevation that is $0-10$ meters. The green color pattern is $10-20$ meter slope, the blue color is between $20-30$ and lastly, the light grey color in the map represents the highest hill. Most of the flood event occurs near the open sea toward the outlet because of the low elevation.

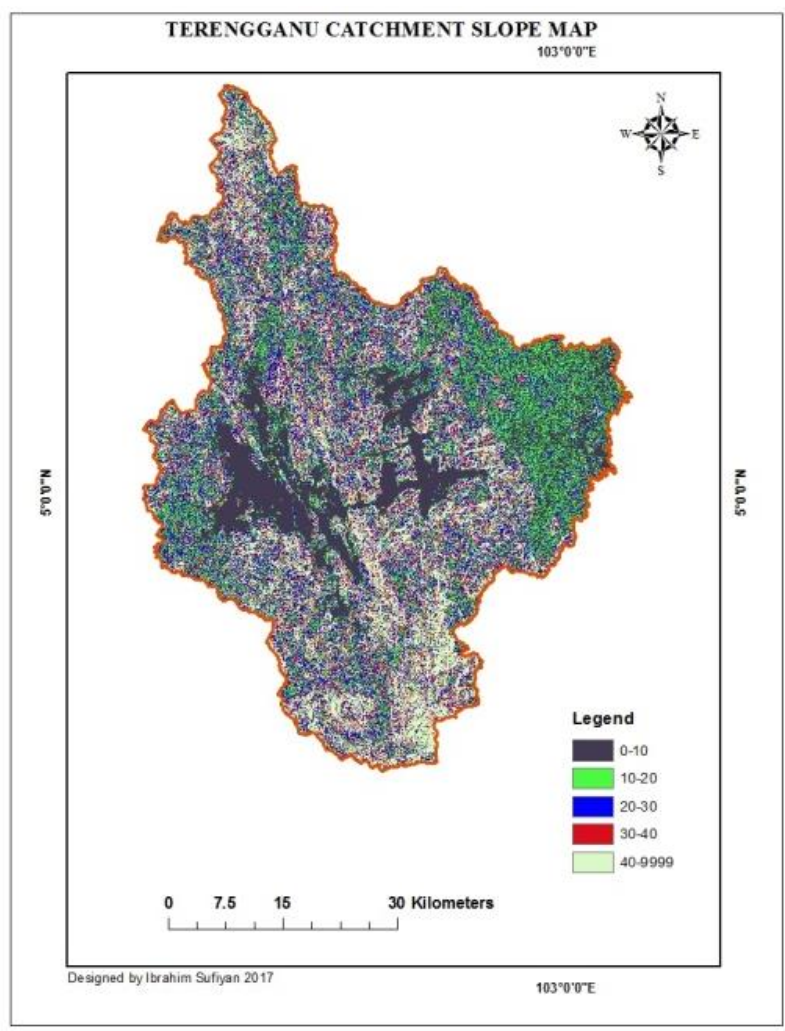

Figure 7: Slope map of Kuala Terengganu River Catchment

\subsection{Flow Direction}

The water flow pattern and direction are from the highland to lowland. The flow was directed toward the river (Sungai) Terengganu outlet and empty into the South China Sea as shown in figure 8. The flow direction has vital relevance in terms of water flow and movement within the Terengganu catchment. Each flow direction has numbers of counts. For example, flow direction number 1 has 604140 flow counts. However, the flow directions also follow the slope gradient into different outlets. The hydro-counts determine how big the sub-flow generates and the location of each flow as indicated in Table 4 below; 
Table 4: flow direction and locations

\begin{tabular}{|l|l|l|}
\hline Flow Direction ID & No of Flow & Locations \\
\hline FLOWDIR 1 & 604140 & $102^{\circ} 48^{\prime} 36.532^{\prime \prime} \mathrm{E} 5^{\circ} 0^{\prime} 39.423^{\prime \prime} \mathrm{N}$ \\
\hline FLOWDIR 2 & 286963 & $102^{\circ} 40^{\prime} 1.504^{\prime \prime} \mathrm{E} 5^{\circ} 7^{\prime} 17.142^{\prime \prime} \mathrm{N}$ \\
\hline FLOWDIR 4 & 497406 & $102^{\circ} 40^{\prime} 2.652^{\prime \prime} \mathrm{E} 5^{\circ} 4^{\prime} 7.508^{\prime \prime} \mathrm{N}$ \\
\hline FLOWDIR 8 & 270757 & $\begin{array}{l}102^{\circ} 48^{\prime} 10.306^{\prime \prime} \mathrm{E} \\
5^{\circ} 11^{\prime} 20.813^{\prime \prime} \mathrm{N}\end{array}$ \\
\hline FLOWDIR 16 & 504052 & $102^{\circ} 51^{\prime} 45.044^{\prime \prime} \mathrm{E} 5^{\circ} 1^{\prime} 17.089^{\prime \prime} \mathrm{N}$ \\
\hline FLOWDIR 32 & 293313 & $102^{\circ} 39^{\prime} 21.648^{\prime \prime} \mathrm{E} 5^{\circ} 8^{\prime} 40.809^{\prime \prime} \mathrm{N}$ \\
\hline FLOWDIR 64 & 598457 & $102^{\circ} 49^{\prime} 54.499^{\prime \prime} \mathrm{E} 5^{\circ} 1^{\prime} 34.916^{\prime \prime} \mathrm{N}$ \\
& & \\
\hline
\end{tabular}

Figure 8: Flow Direction of the Terengganu River Catchment

\subsection{Individual Sub-basin Flood Risk Model}

The figure 9 below was developed from both the ArcSWAT-HRU and the 3D simulated model basically to append to it and show which zone is severely affected by the flood. There are about 25 sub-basins in the study area. Each of which can stand at different GIS analysis to depict the magnitude of the flood risk. As illustrated in figure 8 above, the flood follows the DEM. Both the slope and the flow direction of the Terengganu river catchment were explained fully in figure 9 and figure 10 respectively. For mitigation action, we can select and predict which sub-basins in the watershed are highly substitutable, vulnerable and liable to flood at a point in time, depending on the intensity and duration of the rainfall at the particular location where the sub-basin is located.

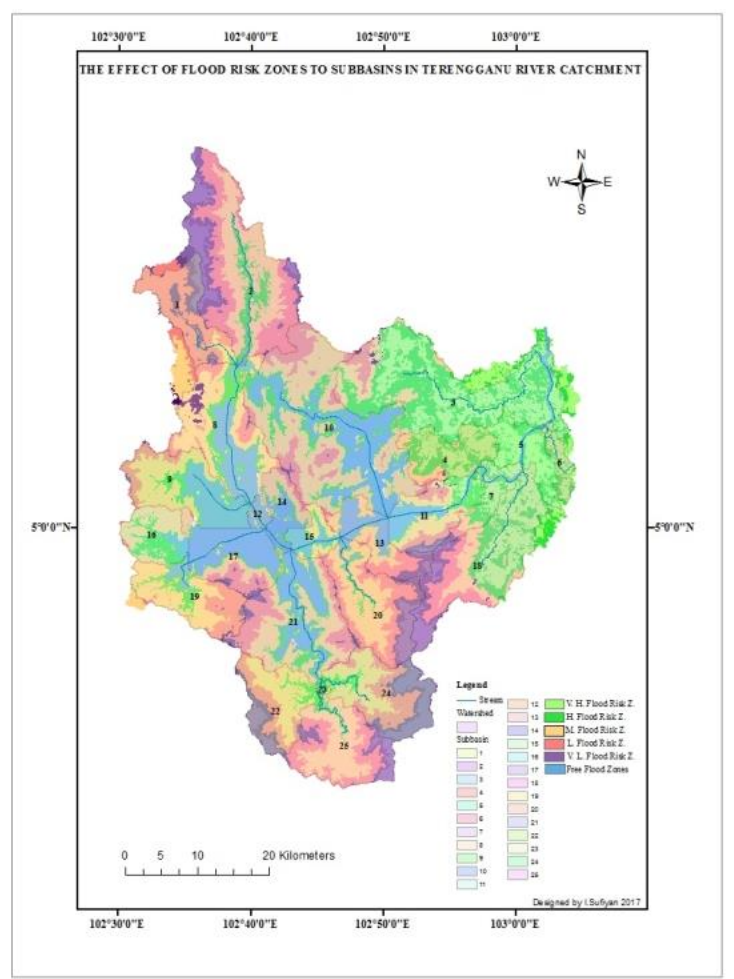

Figure 9: Individual sub-basins flood risk analysis of Terengganu River catchment

\subsection{Flood Simulation Model of Terengganu River Catchment}

The 3D model in figure 10 presents the real-time 3D simulation with the blue color representing the water as it flows from the high slope gradient. The type of the flood mostly experience within these zones Peninsular Malaysia is a flash flood. It occurs during the period of peak rainfall (monsoon) from November to late January causing flood event that ranges from 1 to $2 \mathrm{~m}$ of the slope will be flooded with an increase in rainfall intensity perhaps two to three days of continues rain shower. As it happens recently on November 30 to December 1, 2017, area around Gong Badak was flooded with about 40 houses were affected. If the water level increases from the tributaries of the river, then we expect and predicts very high flood risk of $3 \mathrm{~m}$ above the predicted flood within the Terengganu River catchment but rarely happen for decades.

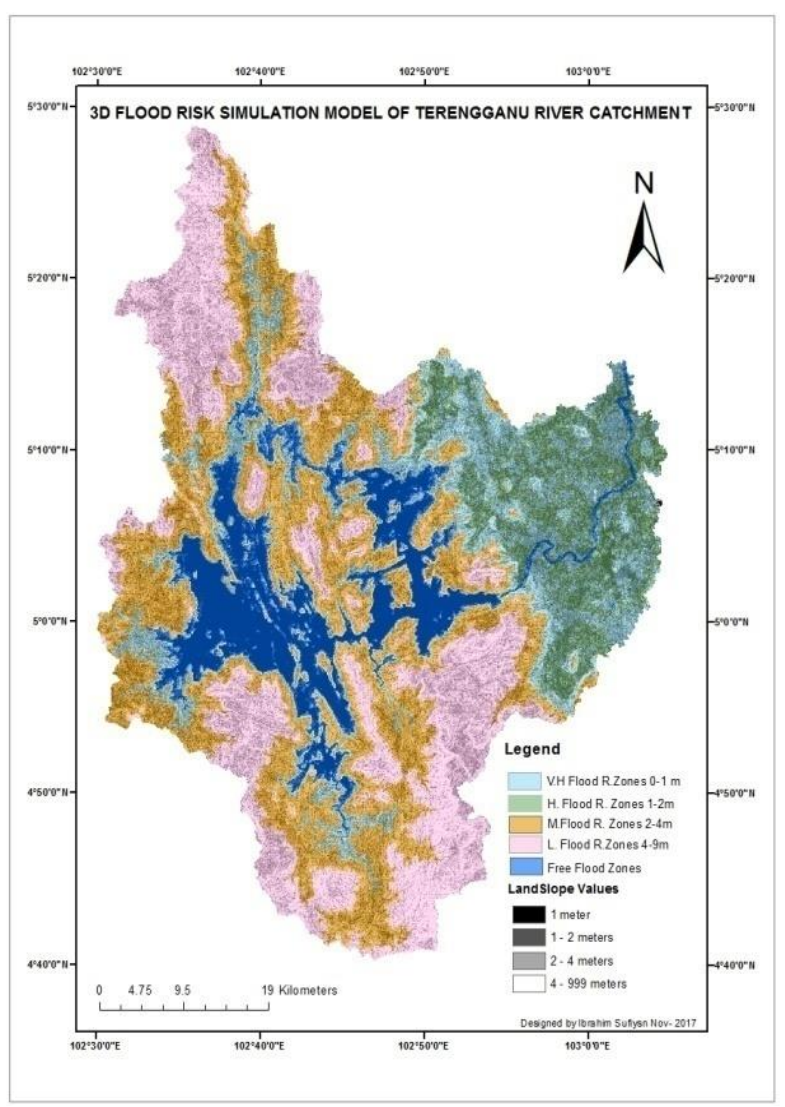

Figure 10: Flood Simulation Model of the Terengganu River Catchment

\section{CONCLUSION}

Flood protection is one of the essential regulating ecosystem services, especially the forest zones which have the highest percent of the total land cover in Terengganu watershed. The subbasins parameters provide water regulation baes on the nature of the terrain or digital elevation model (DEM). The coastal area attracts tourist, especially where the weather parameter is moderate. Terengganu River is emptied into South-China Sea and attraction sites-view and water-view like the Kenyir Lake generates revenue to Malaysia. Recently, there is a need to develop more eco-tourism so that to harness the untapped resources from the Kenyir Lake. There is need to employ the adoption of SWAT application in all ramifications of marine and hydrology so that to cover recent trends in solving environmental issues and problems. The SWAT HRU results should be repeated after every 2-3 years so that to ensure correct and proper predictions within the river catchment under study. When using 3D analysis, we need to obtain high-resolution from the satellite images so that the ArcScene simulation will be clear and precise. Human increase in number, as well as improvement in general standard of living per capita income, raise the status of the population and its composition. The discarded materials from refuse also block the ways or drainage. This excess water will not get outlets so it might result in a flood. lack of proper drainage is one of the challenges facing developing countries. Therefore, Malaysia is increasing and the human activities are tempering the natural equilibrium of the environment. This gives way to tremendous change of land cover. Once the forest is cleared then the resultant effects are climate modification and soil charge dynamics in terms of structures and compositions leading to land degradation, erosion and flood. 


\section{REFERENCES}

[1] Ahmad, M., Zani, N.M., Hashim, K.F. 2015. Knowledge sharing behavior among flood victims in Malaysia. ARPN Journal of Engineering and Applied Sciences, 10(3), 968-976.

[2] Arnold, J.G., Srinivasan, R., Muttiah, R.S., Williams, J.R. 1998. Large area hydrologic modeling and assessment part I: Model development1. Wiley Online Library.

[3] Baker, T.J., Miller, S.N. 2013. Using the Soil and Water Assessment Tool (SWAT) to assess land use impact on water resources in an East African watershed. Journal of Hydrology, 486, 100-111.

[4] Bartosova, A., Clark, D.E., Novotny, V., Taylor, K.S. 2000. Using GIS to evaluate the effects of flood risk on residential property values.

[5] Brzozowski, J., Miatkowski, Z., Śliwiński, D., Smarzyńska, K., Śmietanka, M. 2011. Application of SWAT model to small agricultural catchment in Poland. Journal of Water and Land Development, 15, 157166.

[6] Coppin, P., Jonckheere, I., Nackaerts, K., Muys, B., Lambin, E. 2004. Review ArticleDigital change detection methods in ecosystem monitoring: a review. International Journal of Remote Sensing, 25(9), 1565-1596.

[7] Fukunaga, D.C., Cecílio, R.A., Zanetti, S.S., Oliveira, L.T., Caiado, M.A.C. 2015. Application of the SWAT hydrologic model to a tropical watershed in Brazil. Catena, 125, 206-213.

[8] Galván, L., Olías, M., de Villarán, R.F., Santos, J.M.D., Nieto, J.M., Sarmiento, A.M., Cánovas, C.R. 2009. Application of the SWAT model to an AMD-affected river (Meca River, SW Spain). Estimation of transported pollutant load. Journal of Hydrology, 377(3), 445-454.

[9] Hassan, A.J., Ab. Ghani, A., Abdullah, R. 2006. Development of flood risk map using GIS for Sg. Selangor Basin. Proceeding 6th International Conf. on ASIA GIS, 9-10 Mac, UTM, 1-11.

[10] Islam, M., Sado, K. 2000. Flood hazard assessment in Bangladesh using NOAA AVHRR data with the geographical information system. Hydrological Processes, 14(3), 605-620.
[11] Kemanusian, F. 2007. Coastal Flood Phenomenon in Terengganu, Malaysia: Special Reference to Dungun "Muhammad Barzani Gasim," Jumaat H. Adam, "Mohd Ekhwan Hj Toriman," Sahibin Abd. Rahim and "Hafizan Hj. Juahir. Research Journal of Environmental Sciences, 1(3), 102-109.

[12] Lin, G.F., Chou, Y.C., Wu, M.C. 2013. Typhoon flood forecasting using an integrated two-stage support vector machine approach. Journal of Hydrology, 486, 334-342.

[13] Miller, S.N., Semmens, D.J., Goodrich, D.C., Hernandez, M., Miller, R.C., Kepner, W.G., Guertin, D.P. 2007. The automated geospatial watershed assessment tool. Environmental Modelling \& Software, 22(3), 365-377.

[14] Muhammad-Barzani, G., Ismail, B.S., Rahim, S. 2007. Hydrology and Water Quality Assessment of the Tasik Chilli's Feeder Rivers, Pahang, Malaysia.

[15] Onuşluel Gül, G., Rosbjerg, D. 2010. Modeling of hydrologic processes and potential response to climate change through the use of a multisite SWAT. Water and Environment Journal, 24(1), 21-31.

[16] Stehr, A., Debels, P., Romero, F., Alcayaga, H. 2008. Hydrological modeling with SWAT under conditions of limited data availability: evaluation of results from a Chilean case study. Hydrological Sciences Journal, 53(3), 588-601.

[17] Stolte, J., Ritsema, C.J., Bouma, J. 2005. Developing interactive land use scenarios on the Loess Plateau in China, presenting risk analyses and economic impacts. Agriculture, Ecosystems \& Environment, 105(1), 387399.

[18] Thampi, S.G., Raneesh, K.Y., Surya, T.V. 2010. Influence of scale on SWAT model calibration for streamflow in a river basin in the humid tropics. Water Resources Management, 24(15), 4567-4578.

[19] Zhang, X., Srinivasan, R., Hao, F. 2007. Predicting hydrologic response to climate change in the Luohe River basin using the SWAT model. Transactions of the ASABE, 50(3), 901-910. 